\title{
MORAL CONDITIONS FOR METHODOLOGICALLY RATIONAL DECISIONS
}

\author{
Jan F. Jacko (2018) Moral conditions for methodologically rational decisions. Poznan Studies in the
} Philosophy of the Sciences and the Humanities, 111: 209-223.

Preprint

\begin{abstract}
Summary
The study's main thesis is that respect for some moral values is a condition for methodologically rational decisions, namely, decisions which do not satisfy the condition are either not methodologically rational at all, or not fully rational. The paper shows supporting arguments for the thesis in terms of the philosophical theories by Aristotle, Immanuel Kant, Tadeusz Kotarbiński, Max Weber, Jean-Paul Sartre and some other thinkers. Their presentation undergoes phenomenological analysis of the phenomenon of decision making.
\end{abstract}

\section{Introduction}

The objectives of a decision are of an instrumental value (instrumental values) for the agent, when (in his/her opinion) they are conditions for, or conductive to some other objectives he/she aims to achieve. The objectives of a decision are of an autotelic value (autotelic values) for the agent, when he/she appreciates them regardless of their instrumental value (they are valuable for him/her regardless of whether he/she thinks that their implementation would bring some benefit other than their achievement). As noted by among others, Max Weber, the agent perceives them as "values in themselves" or "intrinsic values" (Ger. Eigenwert). (Weber, 1985, p. 565).Such objectives are called "moral values" in this study.

The main thesis of the study is that respect for some moral (autotelic) values is a condition for methodologically rational decisions, namely, the decisions which do not satisfy the condition are either not methodologically rational at all or not fully rational. It is a moral condition for methodologically rational decision making. The paper shows arguments supporting the thesis in theories by Aristotle, Immanuel Kant, Tadeusz Kotarbiński, Jean Paul Sartre, Max Weber and some other thinkers. The authors were selected as they represent a wide spectrum of philosophical theories, while also constituting an original approach and the recognized reference point of the rational decision theory. Their presentation undergoes phenomenological (Smith, 2013) analysis of the phenomenon of rational decision making.

The afore-mentioned definition of autotelic values does not answer the question as to how they exist. Realist (Kim, 2007; Sayre-McCord, 2011) and objectivist (Harrison, 1967a) ethical theories assume that moral values are real entities and moral judgements may be true or false. Followers of antirealist theories in ethics (ethical subjectivism) maintain that moral 
values are not real and moral judgments about them are neither true, nor false (Joyce, 2015; Harrison, 1967b). Ethical anti-relativists maintain that moral values are intrinsic and not relative to other factors (such as circumstances or assessments). Ethical relativists assume that moral values are not intrinsic - they are either relations or functions of human decisions and actions. (Brandt, 1967, p. 75-76; Garnett, 1944; Gowans, 2012; Hollis \& Lukes, 1982; Jarvie, 1983; Joyce, 2015; Rorty, 1991; Swoyer, 2014) The study shows how the main thesis of this study can be justified and what it means in the contexts of realist (Aristotle), anti-realist (Sartre), anti-relativist (Aristotle, Kotarbiński), relativist (Sartre, Weber) and intermediate between anti-relativism and relativism (Kant) ethical theories.

The first section specifies the concept of a methodologically rational decision which is referred to in this paper. Sections 2, 3, 4 show some moral conditions for rational decisions: the agent's respect for his/her own existential commitments and for some autotelic values. In section 5 we show that the afore-mentioned conditions imply some moral criteria of efficiency assessment.

\section{The Concept of Methodologically Rational Decisions}

Among others, Tadeusz Kotarbiński (1973) distinguishes between factual (objective) rationality of actions and methodological (subjective) rationality of their intentions. The first one is a peculiar relation between intentions and consequences (effects) of actions. Their factual rationality consists of their "adaptation to reality" in terms of their effectiveness (effectivity) and efficiency (economy). (Kotarbiński, 1973, p. 123) Their effectiveness is their capability of producing desired results. Efficiency of actions is an accomplishment of, or ability to accomplish a job with a minimum expenditure of resources (for example, time and effort) which the agent has at his/her disposal. Effectivity and efficiency of an action are prerequisites for its factual rationality. Their conjunction is the sufficient condition for factual rationality of actions. Factually irrational action does not meet the effectivity/efficiency conditions - it is ineffective and/or inefficient. Factual rationality (Pol. racjonalność rzeczowa) is also known as "objective," "economic," "formal" rationality. (Dennis, 2012; Hey, 1993; Kleszcz, 1998)

Although Kotarbiński does not explicitly write about rational decisions, his conception of methodological rationality (Pol. racjonalność metodologiczna) denotes their peculiar quality. Three prerequisites for methodologically rational decisions are relevant to this study. The decisions are as follows:

(x) consistent with the knowledge of the decision maker,

(y) motivated by rational beliefs,

(z) intend factually rational (effective and efficient) actions.

(x) A methodologically rational agent (who makes methodologically rational decisions) investigates the reasons for decisions and accommodates them within his/her knowledge (by knowledge, we mean all of the information available to the agent, which, given its justification, he or she should assign the probability to act on as if it was true). Methodologically irrational agents (who make methodologically irrational decisions) neglect their knowledge in their decision making. For example, they can ignore information on the risk or relevant circumstances of their actions. (Kotarbiński, 1973, p. 123). 
(y) Methodologically rational decisions are motivated by rational beliefs. Assertion of rational beliefs is symmetric to their justification: A methodologically rational person is sure of his/her beliefs proportionally to their justification; he/she is more certain of more justified beliefs and less sure of lesser justified beliefs. For example, he/she is more certain of more probable than of less probable predictions, while also willing to change opinions when proven wrong. Methodologically irrational decisions are not motivated by rational beliefs. A methodologically irrational agent can maintain beliefs irrespective of their justification. For example, he/she can be more certain of less probable than of more probable predictions or can maintain their beliefs when proven wrong (Bortolotti, 2010; Jacko, 2016; Pagin, 2014).

(z) Methodologically rational agents intend to take factually rational action (its effectiveness and efficiency). This condition does not prejudge how their knowledge relates to reality. They may be in error and take factually irrational actions despite the intention stated above (Simon, 1992).

The afore-mentioned conditions also apply to decisions made with a high degree of uncertainty. For example, religious beliefs and decisions can be methodologically rational (though not always), as among others, Józef Maria Bocheński (1990) shows.

The methodologically rational attitude ${ }^{1}$ is the inclination to make methodologically rational decisions (satisfying the conditions $\mathrm{x}, \mathrm{y}, \mathrm{z}$ ). Thanks to such an attitude, agents are capable of making decisions of this kind despite endogenous (e.g. being fearful, afraid, or tired) or exogenous (e.g. adverse circumstances, environment pressure) determinants. The ancient men of wisdom referred to this attitude in their concept of virtue (gr. $\dot{\alpha} \rho \varepsilon \tau \dot{)})$. (Jaeger, 1986, 1989; Veath, 2003).

Despite the fact that the afore-mentioned conception of methodologically rational decisions is embedded in philosophy (Gomez, 2014), the conception is of a regulatory nature - the conditions for rational decisions may be described either in a way that is similar to the one presented in the article or in a much different way. One can also indicate more prerequisites for rational decisions (Abell, 1991; Auspitz, Gasparski, Mlicki, Szaniawski, 1992; Coleman, Fararo, 1992; Dennis, 2012; Gerrard, 1993; Hey, 1993; Kleszcz, 1998; Kosiorowski, 2005; Krasnodębski, 1991; Veatch, 2003; Zafirowski, 2003; Zey, 1997). In this text the terms "rational decisions" or "rational attitudes" denote methodologically rational decisions and attitudes.

Weber shows two aspects of the phenomenon defined above as methodological rationality of decisions - their instrumental (Ger. zweckrational) and value (Ger. wertrational) rationality. ${ }^{2}$ The distinction between instrumental and value rationality of decisions concerns two objectives of rational decisions. Instrumentally rational decisions are aimed at effectiveness and value rational decisions are aimed at efficiency. Instrumentally rational decisions select the means, which (according to the knowledge of the decision maker) are

\footnotetext{
${ }^{1}$ Attitude is a system of emotional cognitive and behavioural factors: Its emotional component is your emotional reactions to the subject of attitude (e.g. another person or a problem), its cognitive component is your thoughts and beliefs about the subject of the attitude and its behavioural component is your action, which is observable behaviour towards the subject of attitude (McGuire, 1985).

${ }^{2}$ Weber's concept of rationality of action is subject to criticism. In many areas it lacks precision, and may therefore be interpreted in various ways. Nevertheless, it is recognized as a point of reference in literature (Danielson 1998; Habermas 1984; Kalberg 1980; Oakes 2003).
} 
most effective. Instrumentally irrational decisions do not satisfy the condition - they intend the means, which are (according to the knowledge of the decision maker) unsuccessful, or less successful than their alternatives. (Weber, 1985, p. 565) Value rational decisions respect the commitment of the decision maker to autotelic values and in this way they are aimed at efficiency. Value irrational decisions (at all or in some respect) do not follow the commitment. (Weber, 1985, p. 565) Decisions can be directly or indirectly value irrational they can directly or indirectly refer to autotelic values. In the former case, value irrational decisions do not intend to respect and promote the values. In the latter case, decisions do not have the afore-mentioned intention but they are the practical or logical contradiction of the aims determined by the autotelic values acknowledged by their entity (Callahan 2007; Kalberg 1980; Kim 2007; Kronman, 1983; Oakes 2003; Peukert, 2004; Weber 1985, p. 565; 2011, 2012).

The afore-mentioned concept of value rationality highlights the unity of commitments of a rational entity. As Weber shows, they constitute a dynamic wholeness, because they are by default or directly aimed at achieving a superior objective, which is the autotelic value (aim, goal). They imply a hierarchy of values: Instrumental values are precious to the rational agent, because they are conditions for, or conductive to more important instrumental values and all the instrumental values are precious to him/her because they are conditions for, or conductive to the autotelic value. If a value rational agent has to sacrifice some values, he/she gives priority to higher value over lower values according to his/her hierarchy of values (Weber, 1985, p. 565).

What is indicated above by the term "value rationality", Sartre refers to as the "authenticity" of decisions. In his opinion, it consists of the compliance of particular decisions of the agent with his/her "existential" ("fundamental") choice of, or commitment to the most important values (that design a "project of life", Fr. durée de vie). Particular decisions are authentic when they express this choice. (Crowell, 2004; Flynn, 2013; Heter, 2006; Sartre, 1956, 1988).

\section{Moral Sense of Right Reason}

According to the concept of "the right reason" (Gr. ỏ $\rho \theta$ ó $\left\langle\lambda \gamma_{\gamma} \varsigma\right.$, , Lat. recta ratio), (epistemic) truth is an autotelic (although not always achievable) value and respect for the truth is the volitional prerequisite for rational decisions. The concept was introduced into the Western philosophy by, among others, Socrates, Plato, and Aristotle. It has been clarified by the medieval philosophers, thinkers of the Enlightenment, the Renaissance and those of modern times (Gomez 2014, pp. 252-253).

Some contemporary philosophers, even if they assume ethical relativism, they still can implicitly allude to the concept of the right reason. For example, Sartre perceives the connection of rational (authentic) decisions with knowledge: As he notes, the lack of authenticity can take on a variety of forms, yet in each of them there is a disproportion between what one knows and what one believes in. This state - in the language of existentialism - is called 'bad faith' (Fr. mauvaise foi). It involves self-deception maintaining that one knows what one does not know or one does not know what one knows. It leads to divided or double assertion: it occurs when an agent with the same or two acts of assertion both affirms and denies a judgment. As Sartre maintains, knowledge is the prerequisite for freedom: an agent should take note of how things are in order to be able to 
take a stand against them. When denying their knowledge, agents give up their freedom. Therefore, their respect for their knowledge is the prerequisite for authentic decision making (Sartre, 1956).

For Sartre, respect for knowledge is not a prerequisite for existential commitments as he assumed that they are arbitrary and the ultimate criteria of truth, while also moral assessments. It implies that the qualification of rationality does not apply to existential commitments. Ethical anti-relativists maintain that the afore-mentioned assumption is not justified. For example, Kotarbiński shows that moral norms can be more or less (logically) consistent with each other and more or less grounded in the knowledge of decision makers. As he maintains, methodologically rational agents prefer the most justified solutions from the moral standards at stake, whereas the autotelic values and ethical principles should be selected by methodologically rational decisions (according to common sense, immediate experience and logical principles) and normative ethics should consist of rational beliefs. His "independent ethics" (Pol. etyka niezależna) follows the aforesaid postulates (Kotarbiński, 1958; Szostek, 1971; Woleński, 2006). His conception implies the interdependence between (methodological) rationality and validity of existential commitments: (methodologically) rational decisions validate moral standards, but the decisions cannot be (methodologically) rational without respecting the knowledge of the decision maker (Kotarbiński, 1958, 1958; Szostek, 1971).

Ethical anti-relativists, such as Kotarbiński, take account of the critique of naturalistic fallacy (first noted by David Hume). He does not assume that existential commitments (expressed in "ought to" statements) logically follow from knowledge (expressed in "is" statements) about facts. Nevertheless, he and other ethical anti-relativists maintain that the commitments can be justified in a better or worse manner and rational agents are (morally) obliged to prefer the most appropriately justified existential commitments and moral principles (Brandt, 1967, p. 75-76; Garnett, 1944; Gowans, 2012; Hollis \&Lukes, 1982; Jarvie, 1983; Joyce, 2015; Rorty, 1991; Swoyer, 2014).

The aforesaid exemplary relativist and anti-relativist moral theories differ at some crucial points. For example, they can assume different conceptions and criteria of truth. Nevertheless, they all assume that rational agents respect their own reason. It implies that (epistemic) truth (understood in various ways) is an autotelic (moral) value for rational agents and respect for the truth is a prerequisite for rational decisions.

\section{Moral Objectives of Rational Decisions}

Among others conceptions of Sartre and Weber allude to the philosophy of Immanuel Kant, who outlines the moral objectives of rational decision making. He shows that a rational agent respects logical and causal dependences; while also making decisions based on the principle of effectiveness and efficiency of achieving their objectives. As Kant maintains rational agents are obliged to this kind of decision-making by hypothetical imperatives that require them to respect the necessary and sufficient conditions for the realization of the objectives pursued by the agents. Kant shows that respect to hypothetical imperatives is necessary, albeit not a sufficient condition for rational decisions. Their rationality in his view is about respecting the superior goal of human commitments. Unlike Sartre or Weber, Kant does not assume that this goal is a matter of arbitrary decisions or determined by traditions. As he shows, it is determined by the categorical imperative. Its justification lies in the Kantian concept ("critique") of practical reason which - being the domain of freedom - finds the 
purpose of actions in freedom. According to Kant, rational decisions rely on respecting freedom (of oneself and others) by selecting such actions, which do that in an optimal way. Such a goal is of a formal nature, but in particular circumstances of action, it becomes concretized as knowledge about logical and causal conditions of freedom determines the optimal way to respect the categorical imperative in specific cases (Gellner, 1992; Kant, 2010; Kim, 2007; O’Neill, 2004; Reath, 2012).

Kant prima facie specifies the categorical imperative by his analysis of the experience (phenomenon) of decision-making. This method of an analysis may be applied to particular domains of human activity. For example, Jurgen Habermas (1984) presents this method in his conception of rational communication. As he shows, acts of communication are rational, while simultaneously respecting the nature of communication of which they are instantiations.

Kant and Habermas attempt to avoid ontological or epistemological assumptions, which cannot be justified as prima facie. In effect, their idea of rationality is much more formal than in some realist ethical theories that rely on more developed metaphysical or epistemological assumptions, which allow the specification of more characteristics of rational decision-making. For example, utilitarians assume that rational decisions directly or indirectly intend (individually or socially) useful consequences. The function of (variously defined) utility plays the role of an autotelic value in utilitarian theories. In order to specify and operationalise the function of utility, utilitarians (implicitly or explicitly) assume some conception of human nature and human needs. (Barbera, Hammond, \& Seidl, 1998; Driver, 2014; Hookway, 2013). This solution (usually implicitly) alludes to the theory by Aristotle, who formulated the canonical conception of rational decisions. As Stagyrite shows, the superior goal (highest good) of human rational commitments is happiness (of the agent and

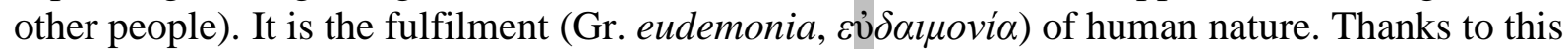
assumption and his concept of human nature, Aristotle specifies the particular objectives of rational decisions (Aristotle, 2002; Kraut, 2016; May; 2010; Veatch, 2003). Moral objectives of rational decisions can also be specified due to some epistemological assumptions. For example some phenomenologists, such as Max Scheler (1925) assume that one can know autotelic values through direct experience, which indicate the moral objectives of rational decision making.

The afore-mentioned theories (by Aristotle, Habermas, Kant, Scheler, utilitarians) show that an action is objectively (factually) rational when it optimises some autotelic (moral) values and a decision is subjectively rational when it intends them. In this sense, respect for some moral values is the prerequisite for rational actions and decisions.

\section{Value versus Instrumental Rationality: Moral Prerequisites for Intending Efficiency}

As among others, Weber suggests, the value rationality of decisions complements their instrumental rationality. Fully rational decisions are both value and instrumentally rational. (Callahan 2007; Kalberg 1980; Kim 2007; Kronman, 1983; Oakes 2003; Peukert, 2004; Weber 1985, p. 565; 2011, 2012). It may seem that at least in some cases value and instrumental rationality may be mutually exclusive. For example, if someone decides to accept the desired promotion and he/she knows that this decision will distance him/her from more important values (goals) according to his/her hierarchy of values, this decision is not 
value rational but instrumentally rational. However, strictly speaking, the decision is instrumentally rational only in respect to the particular goal of the promotion and it is not instrumentally rational in respect to some other goals, which are more important for the agent. Hence, the decision is not fully rational. By way of explanation, the agent decides to sacrifice the more important goal in order to achieve the less important goal (according to his hierarchy of values) - the decision does not intend efficiency. Indeed, one cannot intend the efficiency of one's own actions without respecting one's own knowledge about one's own existential commitments, which define what their efficiency is. As methodologically rational decisions intend efficiency (section 1, condition $\mathrm{z}$ ), their respect for some autotelic values is a prerequisite for methodologically rational decisions. (McKenzie, 2010; Sen, 1977)

\section{Some Implications in Economics, Praxeology and Management Sciences: Moral Criteria of Efficiency Assessment}

As among others, Weber shows, the criteria of efficiency depend on the adopted taxonomy of resources, the taxonomy is determined by the hierarchy of values and the hierarchy depends on the agent's commitment to autotelic values and his/her understanding of their operational meaning. (Callahan 2007; Kalberg 1980; Kim 2007; Kronman, 1983; Oakes 2003; Peukert, 2004; Weber 1985, p. 565; 2011, 2012) Thus, a comprehensive assessment of the efficiency is not complete without taking account of those values that the agent considers to be autotelic. This observation implies moral criteria of efficiency assessment as autotelic values imply some moral norms that translate the values into practice (operationalise them). These norms are the criteria of efficiency assessment. (Honigsheim, 2003) Similarly, Sartre maintains that logical and practical relationships occur between the existential choices and particular decisions of a human. These relationships allow for the assessment of human decisions in terms of their efficiency relating to whether they are successful in expressing and respecting the existential commitment of the agent. Such an assessment has ethical bearing, since the choice of the superior objective is the superior norm of private morality (Flynn, 2013; Heter, 2006a; Sartre, 1989). The afore-mentioned authors prima facie (by their analysis of the phenomenon of rational decision making) justify their thesis on the moral criteria of efficiency assessment.

The thesis can be justified by way of the contexts of relativistic as well as in antirelativistic moral theories. An ethical relativist, "denies that there is any one correct moral evaluation" (Brandt, 1967, p. 75). Sartre is a representative of ethical relativism. He shows that rational (authentic) entities have to commit themselves to an autotelic value and the value implies some moral criteria of efficiency assessment, but the criteria are valid only in the perspective of the commitment to the autotelic value. It implies that the criteria are not universally valid. Ethical anti-relativists assume some universal moral values, which imply some universally valid moral norms and criteria of efficiency assessment. For example, Henry Mintzberg (1982, p. 104) maintains that efficient actions have to promote some "social values". It is the prerequisite for their efficiency. Indeed, he does not specify them, but just shows that some values are not arbitrary and have to be taken into account in terms of efficiency assessment, albeit it is not easy to measure them. As Mintzberg notes, efficiency is not the same as "demonstrated efficiency, proven efficiency, and above all, calculated efficiency" (Mintzberg, 1982, p. 102). As he maintains, efficiency is qualitative and quantitative methods can lead to errors, which consist of overlooking social values in the efficiency assessment (Mintzberg, 1982, p. 103). 
Likewise, some other contemporary theories introduce moral criteria into sciences dealing with the efficiency of actions. Some ongoing discussions of "bounded rationality" (Simon, 1982, 1992), economic rationality (McKenzie, 2010; Sen, 1977) or approaches to risk management (Luetge \& Jauernig, 2013) demonstrate the role of moral attitudes and normative criteria in heuristic intuitive methods (for example, emotional intelligence) of decision making (Arvidsson \& Peitersen, 2016; Brown, 2010; Gasparski, Szaniawski, 1977; Klimczak, 2014; Mintzberg, 1982; 1994; Szaniawski, 1994; Wight, 2015).

\section{Conclusions}

The concepts presented in the herein paper differ in terms of their epistemology, ontology and methodology. Despite their discrepancies, they all show that respect for some autotelic (moral) values is the condition for methodologically rational decisions and decisions which do not satisfy the condition are either not methodologically rational at all, or not fully rational. We present this thesis in sections 2, 3, and 4. Kant, Sartre, Habermas and Kotarbiński prima facie justify it by their (phenomenological) analyses of decision making. Additionally, this is exemplified by Aristotle, Scheler and utilitarians, who have based the thesis on some additional ontological and epistemological assumptions, which are prima facie justified too. It does not have any other proof there. Therefore, the thesis plays the role of the premise in the aforesaid theories and as such, it can be the subject of deliberation and further investigation.

We do not maintain that one cannot successfully investigate efficiency of decisions without taking account its moral conditions. For example, the mathematical theory of games does not have to do it in order to find fitting solutions for some dilemmas. This and similar examples do not prove that the afore-mentioned premise is theoretically or practically useless. As some authors show, the failure to take account of the moral aspects of rational decisions can lead to paradoxes in theory and to counterproductive or socially harmful strategies or practice (Danielson, 1998; Jacko, 2009; McKenzie, 2010; Mintzberg, 1982; Sen, 1977). In section 4 and 5 we show how this premise can supplement the models of rational decision making by indicating the moral aspects of efficiency and ethical criteria of efficiency assessment. Therefore, in some cases the premise may be helpful in explaining, predicting and guiding human decisions. However, in some other cases it may be irrelevant in terms of research when it does not include the moral aspects of decisions making. In any case, one should not dogmatically (without sufficient reason) exclude moral conditions for rational decisions from the research areas. 


\section{References}

Abell, P. (1991). Rational Choice Theory. Hants, Brookfield: Edward Elgar Publishing Ltd.

Aristotle (2002). Nicomachean Ethics. (trans. D. W. Ross) Adelaide: The University of Adelaide Library.

Arvidsson, A., \& Peitersen, N. (2016). The Ethical Economy. Rebuilding Value after the Crisis. Columbia: Columbia University Press.

Auspitz J. L., W. Gasparski, M. Mlicki, K. Szaniawski (Eds.). (1992) Praxiologies and the Philosophy of Economics. New Brunswick, New Jersey: Transaction Publishers.

Barbera, S., Hammond, P., \& Seidl, C. (Eds.). (1998). Handbook of Utility Theory: Volume 1: Principles. Dortreht, Boston, London: Springer Science \& Business Media.

Bochenski J. M. (1965).The Logic of Religion. New York: New York University Press

Bortolotti, L. (2010). Delusions and Other Irrational Beliefs. Oxford, New York: OUP Oxford.

Brandt, R. B. (1967). Ethical relativism. In: P. Edwards (ed.), The Encyclopaedia of Philosophy. Vol.3-4, pp. 75-78. New York: McMillan.

Brown, M.T. (2010). The ethics of economic systems. In: Civilizing the Economy, pp. 178192. Cambridge: Cambridge University Press.

Callahan, G. (2007). Reconciling Weber and Mises on understanding human action. American Journal of Economics and Sociology 66 (5), 889-99.

Coleman J.S., T.J. Fararo, (Eds.), (1992). Rational Choice Theory. Advocacy and Critique. London, New Delhi: SAGE Publications.

Crowell, S. (2004). Existentialism. In: E.N. Zalta (ed.), The Stanford Encyclopaedia of Philosophy, retrieved from http://plato.stanford.edu/archives/spr2016/entries/existentialism/ [accessed: March 5, 2016]

Danielson, P. (ed.). (1998). Modelling Rationality, Morality, and Evolution. New York, Oxford: Oxford University Press.

Dennis, K. (ed.). (2012). Rationality in Economics: Alternative Perspectives. New York: Springer Science \& Business Media.

Driver, J. (2014). The history of utilitarianism. In E.N. Zalta (ed.), The Stanford Encyclopaedia of Philosophy, retrieved from http://plato.stanford.edu/archives/win2014/entries/utilitarianism-history/ [accessed: March 5, 2016]

Fletcher, J. F. (1966). Situation Ethics: The New Morality. Philadelphia: Westminster Press.

Flynn, T. (2013). Jean-Paul Sartre. In: E.N. Zalta (ed.), The Stanford Encyclopaedia of Philosophy, retrieved from http://plato.stanford.edu/archives/fall2013/entries/sartre/ [accessed: March 5, 2016].

Garnett, A. C. (1944). Relativism and absolutism in ethics. Ethics 54 (3), 186-199.

Gasparski, W., Szaniawski, K. (1977). Praxiology and decision theory. In H. Jungermann, G. de Zeeuw (eds), Decision Making and Change in Human Affairs, pp 491-506.

Dordrecht: D. Reidel Publishing Company.

Gellner, E. (1992). Reason and Culture. Oxford, Cambridge: Wiley.

Gerrard B. (Ed.), 1993. The Economics of Rationality. London, New York: Routledge. 
Gomez, V.G. (2014). Rationality and method. In J. Malpas and H.H. Gander (eds.), The Routlege Companion to Hermeneutics, pp. 251-266. Oxon, New York: Routledge.

Gowans, C. (2012). Moral relativism. In E. N. Zalta (ed.), The Stanford Encyclopaedia of Philosophy, retrieved from http://plato.stanford.edu/archives/spr2012/entries/moralrelativism/ [accessed: March 5, 2016]

Habermas, J. (1984). The Theory of Communicative Action. Volume 1. Reason and the Rationalization of Society. Cambridge: Polity Press.

Harrison, J. (1967a). Ethical objectivism. In P. Edwards (ed.), The Encyclopaedia of Philosophy. Vol. 3-4., pp. 71-75. New York: McMillan.

Harrison, J. (1967b). Ethical subjectivism. In P. Edwards (ed.) Encyclopaedia of Philosophy. Vol. 3-4, pp. 78-81. New York: McMillan.

Heter, S. (2006). Sartre's political philosophy. Internet Encyclopaedia of Philosophy. Retrieved from http://www.iep.utm.edu/sartre-p/ [accessed: March 5, 2016]

Hey, J.D. (1993). Rationality is as rationality does. In: B. Gerrard (ed.), The Economics of Rationality, pp. 4-14. London, New York: Routledge.

Hollis, M., \& Lukes, S. (eds.). (1982). Rationality and Relativism. Cambridge: MIT Press.

Honigsheim, P. (2003). The Unknown Max Weber, New Brunswick, NJ: Transaction Publisher.

Hookway, C. (2016). Pragmatism. W E. N. Zalta (Red.), The Stanford Encyclopaedia of Philosophy (Summer 2016), retrieved from http://plato.stanford.edu/archives/sum2016/entries/pragmatism/ [accessed: March 5, 2016]

Jacko, J. F. (2009). Niektóre ontologiczne rozstrzygnięcia Teorii Gier na przykładzie Dylematu Podróżnika i Dylematu Więźnia. Zagadnienia Naukoznawstwa, 3-4 (181182), 429-41.

Jacko, J. F. (2016). Rational informative assertiveness in management communication. Jagiellonian Journal of Management 2, 35-44.

Jarvie, I. C. (1983). Rationality and relativism. In: Thinking about Society: Theory and Practice, pp. 50-69. Dortrecht, Boston, Lancaster: R. Reidel Publishing Company.

Brandt, R. B. (1967a). Ethical relativism. In P. Edwards (Ed.), The Encyclopaedia of Philosophy (Vol. 3-4, pp. 75-78). New York: McMillan.

Brandt, R. B. (1967b). Ethical Relativism. In P. Edwards (Ed.) (Vol. 3-4, pp. 75-78). New York: McMillan.

Fletcher, J. F. (1966). Situation Ethics: The New Morality. Philadelphia: Westminster Press.

Gowans, C. (2012). Moral Relativism. In E.N. Zalta (Ed.), The Stanford Encyclopaedia of Philosophy (Spring 201).

Sayre-McCord, G. (2011). Moral realism. In E.N. Zalta (Ed.), The Stanford Encyclopaedia of Philosophy (Summer 2011). Retrieved from http://plato.stanford.edu/archives/sum2011/entries/moral-realism/

Tatarkiewicz, W. (1919). O bezwzględności dobra. Warszawa: Gebether i Wolf.

Joyce, R. (2015). Moral anti-realism. In E.N. Zalta (ed.), The Stanford Encyclopaedia of Philosophy, retrieved from http://plato.stanford.edu/archives/spr2015/entries/moralanti-realism/ [accessed: March 5, 2016]

Kalberg, S. (1980). Max Weber's types of rationality. The American Journal of Sociology, 85 (5), 1145-1179.

Kant, I. (2010). The Critique of Practical Reason. (trans. T.K. Abbott) Adelaide: The University of Adelaide.

Kim, S.H. (2007). Max Weber. In: E.N. Zalta (ed.), The Stanford Encyclopaedia of Philosophy, retrieved from http://plato.stanford.edu/archives/fall2013/entries/weber/ [accessed: March 5, 2016]. 
Kleszcz, R. (1998). O racjonalności: studium epistemologiczno-metodologiczne. Łódź: Wydawnictwo Uniwersytetu Łódzkiego.

Klimczak, B. (2014). Aksjologiczne uwikłanie ekonomii. Annales. Etyka w Życiu Gospodarczym 17 (1), 9-21.

Kotarbiński, T. (1958). Zasady etyki niezależnej. Studia Filozoficzne 1, 3-13.

Kotarbiński, T. (1973). Traktat o dobrej robocie. Wrocław, Warszawa, Kraków, Gdańsk: Zakład Narodowy im. Ossolińskich.

Kosiorowski D. (2005). Individual rationality versus group rationality in statistical modelling issues. W: Baier, D., Wernecke, K.D. (Eds.), Innovations in Classification, Data Science, and Information Systems, Studies in Classification, Data Analysis, and Knowledge Organization. Berlin Heidelberg: Springer: 239-248.

Kraut, R. (2016) Aristotle's ethics. In: E.N. Zalta (ed.), The Stanford Encyclopaedia of Philosophy, retrieved from http://plato.stanford.edu/archives/spr2016/entries/aristotleethics/ [accessed: 5.03.2016].

Krasnodębski, Z. M. (1991). Działanie i jego racjonalność w perspektywie prakseologicznej i socjologicznej. Prakseologia (1-2), 27-43.

Kronman, A. T. (1983). Max Weber. Stanford, California: Stanford University Press.

Luetge, Ch., J. Jauernig, eds. (2013). Business Ethics and Risk Management. Dortrecht: Springer Science and Business Media.

May, H. (2010). Aristotle's Ethics: Moral Development and Human Nature. London, New York: Continuum.

McGuire, W. (1985). Attitudes and attitude change. In: Lindzey, G., \& Aronson, E. (eds.) Handbook of Social Psychology: Special Fields and Applications, vol. 2. New York: Random House, 233-346.

McKenzie, R. B. (2009). Predictably Rational? In Search of Defenses for Rational Behavior in Economics. Heilderberg, Dortrecht, London, New York: Springer Science \& Business Media.

Mintzberg, H. (1982). A note on that dirty word "efficiency". Interfaces 12 (5): 101-5.

Mintzberg, H. (1994). The Rise and Fall of Strategic Planning. New York: Free Press.

Moore, G.E. (1899). The nature of judgment. Mind 8 (30), 176-193.

Moore, G.E. (1909). Principia Ethica. Cambridge: Cambridge at the University Press.

Oakes. (2003). Max Weber on value rationality and value spheres - critical remarks. Journal of Classical Sociology 3 (1), 27-45.

O’Neill, O. (2004). Kant: rationality as practical reason. In: A.R. Mele, P. Rawling (eds.), The Oxford Handbook of Rationality, pp. 93-109. Oxford: Oxford University Press.

Pagin, P. (2014). Assertion. In: E.N. Zalta (ed.), The Stanford Encyclopaedia of Philosophy, retrieved from http://plato.stanford.edu/archives/spr2014/entries/assertion/ [accessed: 5.03.2016].

Peukert, H. (2004). Max Weber. American Journal of Economics and Sociology 63 (5), 9871020.

Reath, A. (2012). Kant's moral philosophy. In: R. Crisp (ed.), The Oxford Handbook of the History of Ethics, pp. 443-464. Oxford: Oxford University Press.

Brandt, R. B. (1967a). Ethical relativism. In P. Edwards (Ed.), The Encyclopaedia of Philosophy (Vol. 3-4, pp. 75-78). New York: McMillan.

Brandt, R. B. (1967b). Ethical Relativism. In P. Edwards (Ed.) (Vol. 3-4, pp. 75-78). New York: McMillan.

Fletcher, J. F. (1966). Situation Ethics: The New Morality. Philadelphia: Westminster Press. Gowans, C. (2012). Moral Relativism. In E. N. Zalta (Ed.), The Stanford Encyclopaedia of Philosophy (Spring 201). 
Tatarkiewicz, W. (1919). O bezwzględności dobra. Warszawa: Gebetheri Wolf.

Sartre, J. P. (1956). Being and Nothingness. A Phenomenological Essay on Ontology. (trans. H. Barnes). New York, London, Toronto, Sydney: Washington Square Press.

Sartre, J. P. (1988). Existentialism is a humanism. In W. A. Kaufmann (ed., trans. P. Mairet, Existentialism from Dostoyevsky to Sartre, pp. 245-368. New York: Meridian Publishing Company.

Sayre-McCord, G. (2011). Moral realism. In E. N. Zalta (Ed.), The Stanford Encyclopedia of Philosophy (Summer 2011), retrieved from http://plato.stanford.edu/archives/sum2011/entries/moral-realism/ [accessed March 5, 2016]

Scheler, M. (1925). Die Formen des Wissens und die Bildung. Bonn: Vlg von Friedrich Cohen.

Sen, A. K. (1977). Rational fools: A critique of the behavioral foundations of economic theory. Philosophy and Public Affairs 6 (4), 317-344.

Simon, H. A. (1992). Methodological foundations of economics. In J.L. Auspitz, W. Gasparski, M. Mlicki, \& K. Szaniawski (eds.), Praxiologies and the Philosophy of Economics (pp. 25-42). New Brunswick, New Jersey: Transaction Publishers.

Smith, D.W. (2013). Phenomenology. In E.N. Zalta (ed.), The Stanford Encyclopaedia of Philosophy (Winter 2013), retrieved from http://plato.stanford.edu/archives/win2013/entries/phenomenology/ [accessed March $5,2016]$.

Swoyer, C. (2014). Relativism. In The Stanford Encyclopaedia of Philosophy. Stanford: E. N. Zalta (ed.), retrieved from http://plato.stanford.edu/archives/spr2014/entries/relativism/ [accessed March 5, 2016].

Szaniawski, K, (1994). O nauce, rozumowaniu i wartościach. Warszawa: PWN.

Szostek, A. (1971). Etyka jako nauka empiryczna w ujęciu T. Czeżowskiego i T. Kotarbińskiego. Roczniki Filozoficzne 19 (2), 43-57.

Tatarkiewicz, W. (1919). O bezwzględności dobra. Warszawa: Gebether i Wolf.

Veatch, H.B. (2003). Rational Man: A Modern Interpretation of Aristotelian Ethics. Indianapolis: Liberty Fund.

Weber, M. (1985). Gesammelte Aufsätzezur Wissenschaftslehre. Tübingen: Mohr Siebeck.

Weber, M. (2011). Methodology of Social Sciences. (trans. E. Shils, H.A. Finch) New Brunswick, New Jersey: Transaction Publishers.

Weber, M. (2012). Max Weber: Collected Methodological Writings. (eds. S. Whimster \& H. H. Bruun, trans. H. H. Bruun). London; New York: Routledge.

Westacott, E. (2012). Moral relativism. Internet Encyclopaedia of Philosophy, retrieved from http://www.iep.utm.edu/moral-re/ [accessed: March 5, 2016]

Wight, J.B. (2015). Ethics in Economics: An Introduction to Moral Frameworks. Stanford, California: Stanford University Press.

Woleński, J. (2006). Naturalistyczne uzasadnienie etyki niezależnej (spolegliwego opiekuna). Etyka 39, 7-14.

Zafirowski, M. (2003). Human Rational Behaviour and Economic Rationality. Electronic Journal of Sociology 7(2), retrieved from http://www.sociology.org/content/vol7.2/02_zafirovski.html [accessed: March 5, 2016]

Zey, M. (1997). Rational Choice Theory and Organizational Theory: A Critique. London, New Delhi: SAGE Publications. 